\title{
Characterization of phytoplankton exudates and carbohydrates in relation to their complexation of copper, cadmium and iron
}

\author{
Slađana Strmečki ${ }^{1}$, Marta Plavšíc ${ }^{1, *}$, Sebastian Steigenberger $^{2,3}$, Uta Passow Pa $^{2,4}$ \\ ${ }^{1}$ Ruđer Bošković Institute, Center for Marine and Environ. Research, Zagreb, 10002 Zagreb, Croatia \\ ${ }^{2}$ Alfred Wegener Institute for Polar and Marine Research, 27570 Bremerhaven, Germany \\ ${ }^{3}$ Present address: National Oceanography Centre, Southampton, University of Southampton, Waterfront Campus, \\ Southampton, SO14 3ZH, UK
}

${ }^{4}$ Present address: Marine Science Institute, University of California, Santa Barbara, California 93106, USA

\begin{abstract}
The goal of this study was to investigate if transparent exopolymer particles (TEP), carbohydrates, surface-active substances (SAS), reduced sulfur species (RSS), or thio/amino groups contribute significantly to the complexing capacity of phytoplankton exudates for $\mathrm{Cu}\left(\mathrm{L}_{\mathrm{TOTCu}}\right), \mathrm{Cd}$ $\left(\mathrm{L}_{\mathrm{TOTCd}}\right)$, or $\mathrm{Fe}\left(\mathrm{L}_{\mathrm{TOTFe}}\right)$. Complexing capacities and apparent stability constants $\left(\mathrm{K}_{\mathrm{app}}\right)$ were determined electrochemically for $\mathrm{Cu}$ and $\mathrm{Cd}$ in cultures of the marine diatoms Thalassiosira weissflogii and Skeletonema costatum, and in a culture of the coccolithophore Emiliana huxleyi. Furthermore, the complexing capacity with $\mathrm{Fe}, \mathrm{Cu}$ and $\mathrm{Cd}$ of 4 marine polysaccharides (PS) (phytagel, carrageenan, laminarin and alginic acid) was investigated. As expected, more $\mathrm{Cu}$ than $\mathrm{Cd}$ was complexed in the 3 phytoplankton cultures and in the phytagel solution. Size fractionation of the phytagel solution suggests that the binding capacity for $\mathrm{Cu}$ was more significant in the particulate fraction $(>0.7 \mu \mathrm{m})$, indicating that $\mathrm{Cu}$ was preferably trapped within pores and channels of large hydrogels. In contrast, $\mathrm{Cd}$ binding sites were predominantly found in the fraction $<0.7 \mu \mathrm{m}$, suggesting binding to the outer surfaces of gel particles to be of greater importance for larger ions. The $\mathrm{K}_{\mathrm{app}}$ of the $\mathrm{Cd}$

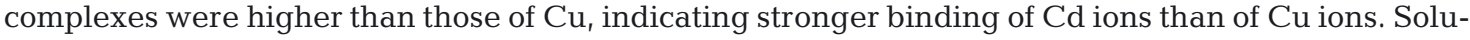
tions of carrageenan, laminarin and alginic acid did not form complexes with either $\mathrm{Cu}$ or $\mathrm{Cd}$, and $\mathrm{Fe}$ binding properties could not be detected for any of the 4 polysaccharide solutions. Thio/amino groups of sulfur-rich 'glutathione' type ligands were found in all phytoplankton cultures and were presumably responsible for the complexation of $\mathrm{Cu}$. No consistent relationship was observed between TEP, carbohydrate concentration, SAS or sulfur content, or with the complexing capacity, emphasizing the high degree of heterogeneity of substance classes responsible for metal binding.
\end{abstract}

KEY WORDS: Complexation $\cdot$ Copper $\cdot$ Cadmium $\cdot$ Iron $\cdot$ Carbohydrate $\cdot$ TEP $\cdot$ Electrochemical method

\section{INTRODUCTION}

Trace metal cycling in the ocean is largely determined by organic matter that acts as metal ligands, subsequently affecting trace metal speciation (Muller et al. 2003). In surface waters, for example, $>99 \%$ of $\mathrm{Cu}, \mathrm{Cd}$ or $\mathrm{Fe}$ is complexed to organic ligands (Bruland
1992, Buck \& Bruland 2005). Several substance classes, including amino acids (e.g. glutathione-like), humic substances originated from aged and microbially modified organic matter, sulfur-rich substances, and transparent exopolymer particles (TEP), have been postulated to play a central role in trace metal binding and their biochemical cycling (Leal et al. 1999, Quigley 
et al. 2001, Benner 2002, Laglera \& van den Berg 2003, Muller et al. 2003, Blake et al. 2004 Bhaskar \& Bhosle 2006, Laglera \& van den Berg 2006, Dryden et al. 2007, Zhang et al. 2008). Phytoplankton exudates and their derivates contribute appreciably to this pool of metal ligands (Bruland et al. 1991, Aluwihare \& Repeta 1999, Bhaskar \& Bhosle 2006, Lorenzo et al. 2007), but metal complexing properties differ in organic matter derived from different sources. Marine metal ligands are specific for certain metals, and ligands that bind different metals differ physicochemically. As a result of this complexity, temporal and spatial variability of the speciation of any one metal in the ocean is high (Croot 2003, Wagener et al. 2008), and individual ligands are not well characterized.

Cysteine- and glutathione-like substances, which are phytoplankton derived amino acids, are known to act as trace metal ligands (Lorenzo et al. 2007). Glutathione is an important $\mathrm{Cu}$-ligand responsible for the nearly complete complexation of $\mathrm{Cu}$ (Ross et al. 2003).

TEP, which are formed abiotically from dissolved precursors released by phytoplankton and bacteria (Passow 2002), are rich in acidic polysaccharides (PS) (especially sulfated ones), which make them extremely surface active (Mopper et al. 1995, Zhou et al. 1998). TEP and their dissolved precursors exhibit a high affinity to thorium and Fe (Honeyman \& Santschi 1991, Guo et al. 2002, Quigley et al. 2002, Passow et al. 2006, Santschi et al. 2006, Zhang et al. 2008), and specifically alginic acid and carrageenans are known to bind metal ions (Gimenez et al. 1995, Kim et al. 1995). Concentrations of nickel $(\mathrm{Ni})$, chromium $(\mathrm{Cr})$ and $\mathrm{Zn}$ in the 0.2 to $0.8 \mu \mathrm{m}$ size-range correlated well with TEP turnover rate in a lagoon off New Caledonia, suggesting that submicron TEP complex metals, but that hydrodynamically controlled reactivity affects their ability to adsorb metals (Mari et al. 2009). Consequently, TEP have also been postulated to play a central role in the cycling of trace metals (Verdugo et al. 2004, Santschi et al. 2006).

Surface-active substances (SAS), which are also derived largely from diatom exudates (Croot et al. 2007), include a variety of organic substances (proteins, PS, lipids, humic type substances) which possess hydrophobic (e.g. fatty acid chains, aromatic rings, hydrocarbons) and hydrophilic functional groups (e.g. $\mathrm{NH}_{2}$, $\mathrm{COOH}, \mathrm{OH}, \mathrm{SH}$ ) and therefore participate in electrostatic and hydrophobic interactions (Ćosović 1985, Ćosović 2005). SAS act as metal ligands and bind $\mathrm{Cu}$ well (Plavšić et al. 2006). Operationally defined, SAS accumulate at phase boundaries, e.g. at the seawateratmosphere boundary or the particle surface-seawater boundary (Liss \& Duce 1997).

The existing methods for these phytoplanktonderived exudation products, that appear to play such a large role in trace element cycling, are semi-quantita- tive. And although TEP, SAS, cysteine- and glutathione-like substances and even carbohydrates are often cited as potential ligands for trace elements, none of these substance classes is well enough characterized to determine the degree of overlap or to allow a direct comparison. Thus we attempted to look into their functional similarity, by investigating whether their respective presence was correlated with trace metal binding.

We present data on the complexing capacity of phytoplankton exudates and PS solutions used as models for TEP and precursors, to test the hypothesis that substances characterized as TEP, carbohydrates, SAS and reduced sulfur species (RSS) all act as trace metal ligands, and to determine the degree of overlap between these different substance classes. Specifically, we determined the complexing capacity for $\mathrm{Cu}$ and $\mathrm{Cd}$ (Scoullos et al. 2006) using electrochemical methods (differential pulse anodic stripping voltammetry, DPASV). Additionally we used competitive ligand exchange cathodic stripping voltammetry (CLE-CSV) (Croot \& Laan 2002) to measure the Fe binding strength of the same model substances, and square wave voltammetry (SWV) scans to identify $\mathrm{Fe}^{3+}$ complexes with these substances. In parallel, we characterized the organic matter by using (1) constant-current chronopotentiometric stripping analysis (CPSA) to detect catalytic groups containing nitrogen $(\mathrm{N})$, sulfur $(\mathrm{S})$, phosphorus $(\mathrm{P})$ or oxygen $(\mathrm{O})$ atoms (Ciglenečki et al. 2003, Strmečki et al. 2010); (2) a voltammetric method to determine the concentration of RSS (Ciglenečki \& Ćosović 1996), (3) a voltammetric method to determine the concentration and type of SAS adsorbed on the mercury electrode (Ćosović 1985) and (4 and 5) colorimetric methods to determine concentrations of TEP (Passow \& Alldredge 1995) and carbohydrates, i.e. PS and monosaccharides (MS) (Myklestad et al. 1997).

\section{MATERIALS AND METHODS}

Preparations of samples. Three marine phytoplankton cultures - 2 diatoms (Bacillariophyceae), Thalassiosira weissflogii and Skeletonema costatum, as well as the coccolithophore (Prasynophyceae) Emiliana huxleyi-were used for experiments with exudates. Cultures were not axenic. Cultures were grown in $\mathrm{f} / 2$ media at $15^{\circ} \mathrm{C}$, under a $16: 8 \mathrm{~h}$ light:dark cycle at 30 to $40 \mu \mathrm{mol} \mathrm{m}{ }^{-2} \mathrm{~s}^{-1}$ light. The f/2 media (Guillard \& Ryther 1962) was based on filtered $(0.45 \mu \mathrm{m}$ nitrocellulose membrane, Millipore) seawater from the North Sea. Besides phosphate, nitrate, silica, and vitamins, the culture medium contained metal ions and $\mathrm{Na}_{2}$ EDTA. EDTA is added to complex the metal ions to reduce their toxicity at high concentrations. To ensure that the added EDTA or metal ions would not affect our mea- 
surements, we calculated EDTA concentrations in the media according to the CHEAQS Pro (Chemical Equilibria in Aquatic Systems) program (Release P2007.1) (Verweij 2007, http:// home.tiscali.nl/cheaqs). Our calculations indicate that concentrations of free EDTA ${ }^{4-}$ (concentration of $10^{-14} \mathrm{M}$ ) in the media were negligible, while other EDTA species, e.g. $\mathrm{H}_{2}\left(\right.$ EDTA $^{2-}$, were present at even lower concentrations $\left(10^{-15} \mathrm{M}\right)$. The concentration of added Fe ions (as total dissolved species) was $10^{-12} \mathrm{M}$, which means that $10^{-15} \mathrm{M}$ Fe was added to make the media $(1 \mathrm{ml}$ of trace metal mix added to 11 of filtered seawater). Other metal ions were added at concentrations of $10^{-11} \mathrm{M}$. The final metal concentrations in the media were thus too low to seriously affect our measurements of $\mathrm{Cu}\left(\mathrm{L}_{\mathrm{TOTCu}}\right)$ or $\mathrm{Cd}$ $\left(\mathrm{L}_{\text {TOTCd }}\right)$ complexing capacity, which were about 2 orders of magnitude higher.

All cultures were harvested at cell concentrations of $\sim 5 \times 10^{6}$ cells $^{-1}$ in their stationary phase. Stationary phase was triggered by high cell densities leading to self shading and inorganic carbon limitation, as cultures were not bubbled. Before analysis, cultures were diluted with a $\mathrm{NaCl}-\mathrm{Milli}-\mathrm{Q}$ solution $(0.55 \mathrm{M})$ at a dilution factor of 1:5 by volume (10 $\mathrm{ml}$ culture in $50 \mathrm{ml}$ total volume).

Model substances. Phytagel, alginic acid, laminarin and carrageenan (all from SIGMA) produce a clear colorless gel in seawater, and such solutions were used as model substances. Phytagel is an agar substitute produced by bacterial transformation, consisting of glucuronic acid, rhamnose and glucose and has an average molecular weight (MW) of $10^{6} \mathrm{Da}$. An unfiltered solution, as well as 2 filtrates $(0.2 \mu \mathrm{m}$ Pall Corp. Acrodisc syringe filter and $0.7 \mu \mathrm{m}$, Whatman GF/F), of phytagel were analyzed. Laminarin is a PS consisting of glucose and manitol generated by brown algae. The PS 1-carrageenan is a sulphated PS and consists of D-galactose units (MW = 3.5 to $7.5 \times 10^{5} \mathrm{Da}$ ). Alginic acid consists of D-manuronic + L-glucuronic acids $\left(\mathrm{MW}=1\right.$ to $60 \times 10^{4} \mathrm{Da}$ ). Laminarin, l-carrageenan and alginic acid, which are all found in marine waters, are known to abiotically form gel particles similar to natural TEP (Passow \& Alldredge 1995). In solutions these 4 PS exist as a size continuum from truly dissolved to particulate with gel particles several 10s to 100 s of micrometers.

The solutions of laminarin, l-carrageenan, alginic acid and phytagel were prepared for SAS, $\mathrm{L}_{\mathrm{TOTCu}}$ $\mathrm{L}_{\text {TOTCd }}$ and CPSA measurements by mixing the respective PS in a $25 \mathrm{ml}$ (or $50 \mathrm{ml}$ ) flask with $2.5 \mathrm{ml}$ (or $5 \mathrm{ml}$ ) of $5.5 \mathrm{M} \mathrm{NaCl}$ solution and filling the flask with $\mathrm{MQ}$ water (end concentration of $10 \mathrm{mg} \mathrm{l}^{-1}$ or $5 \mathrm{mg} \mathrm{l}^{-1} \mathrm{PS}$ in $0.55 \mathrm{M} \mathrm{NaCl}$ solution). The PS solutions were then shaken for $4 \mathrm{~h}$ on a mechanical shaker table to enhance the formation of particles. An unfiltered solution, as well as 2 filtrates $(0.2 \mu \mathrm{m}$ Pall Corp. Acrodisc syringe filter and $0.7 \mu \mathrm{m}$, Whatman GF/F) of phytagel were analyzed.

For the SWV scans, solutions of 0.1 to $2 \mathrm{~g} \mathrm{l}^{-1}$ laminarin, 1 -carrageenan and alginic acid in $0.55 \mathrm{M} \mathrm{NaCl}$ were prepared and adjusted to a $\mathrm{pH}$ of 8 , whereas for CLE-CSV measurements UV pre-treated organic-free seawater was used as a solvent.

Electrochemical instrumentation. $\mathrm{L}_{\mathrm{TOTCu}}, \mathrm{L}_{\mathrm{TOTCd}}, \mathrm{RSS}$ and CPSA measurements were performed with a $\mu$ Autolab analyzer (Eco Chemie) connected to a 663 VA stand (Metrohm), with a static mercury drop electrode (SMDE) as the working electrode. The reference electrode was an $\mathrm{Ag} / \mathrm{AgCl}(3 \mathrm{M} \mathrm{KCl})$. A platinum electrode served as the auxiliary electrode. Identification of $\mathrm{Fe}^{3+}$ complexes and their stability constants was performed on a Metrohm VA 757 voltammeter (Metrohm).

Complexing capacity and stability constants of $\mathbf{C u}$ and $\mathrm{Cd}$. $\mathrm{Cu}$ complexing capacities were determined by DPASV as described previously (Plavšić et al. 1982, Scoullos et al. 2006). DPASV was applied under the following conditions: modulation time $0.04 \mathrm{~s}$, interval time $0.31 \mathrm{~s}$, modulation amplitude $25 \mathrm{mV}$, and step potential $5 \mathrm{mV}$. The deposition time was $60 \mathrm{~s}$ at $-0.6 \mathrm{~V}$ for $\mathrm{Cu}$ and $-0.9 \mathrm{~V}$ for $\mathrm{Cd}$ measured versus an $\mathrm{Ag} / \mathrm{AgCl}$ (3 $\mathrm{M} \mathrm{KCl)}$ reference electrode. We applied the direct titration method by gradually adding more metal ions to the sample. First, a solution of $0.55 \mathrm{M} \mathrm{NaCl}$ in $\mathrm{MQ}$ water was titrated with $\mathrm{Cu}$ and $\mathrm{Cd}$ ions, respectively, to determine the sensitivity $\mathrm{S}$ of the method for both metals. Second, a $0.55 \mathrm{M} \mathrm{NaCl}$ solution with phytoplankton culture or a carbohydrate added was titrated in the same way. These data can be linearized to calculate the apparent $\mathrm{Cu}$ complexing capacity and the corresponding apparent stability constant for each metal (Ružić 1982, van den Berg 1982).

The binding strength of metal-ligand-complex with respect to free metal is represented by its apparent stability constant $\mathrm{K}_{\mathrm{app}}$

$$
[\mathrm{M}] /[\mathrm{ML}]=[\mathrm{M}] / \mathrm{L}_{\mathrm{TOT}}+1 / \mathrm{K}_{\mathrm{app}} \mathrm{L}_{\mathrm{TOT}}
$$

where [ML] is the amount of metal bound to the ligand, and $[\mathrm{M}]$ and $\left[\mathrm{L}_{\mathrm{TOT}}\right]$ are the uncomplexed (electrochemically labile) metal ion and ligand concentrations in the system. The total metal concentration present in the sample is $\left[\mathrm{M}_{\mathrm{TOT}}\right]=[\mathrm{M}]+[\mathrm{ML}]$, while the total ligand concentration is $\left[\mathrm{L}_{\mathrm{TOT}}\right]=[\mathrm{L}]+[\mathrm{ML}]$. $[\mathrm{M}]$ and $[\mathrm{ML}]$ are calculated from the titration data, as

and

$$
[\mathrm{M}]=\mathrm{I}_{\mathrm{p}} / \mathrm{S}
$$

$$
[\mathrm{ML}]=\left[\mathrm{M}_{\mathrm{TOT}}\right]-[\mathrm{M}]
$$

where $I_{p}$ is the height of the DPASV metal ion peak, and $\mathrm{S}$ the sensitivity of the DPASV method for the respective labile metal ion. To obtain the complexing capacity and the apparent stability constant, titration 
data are linearly transformed assuming a 1:1 ratio of metal to ligand in the complex (Ružić 1982, van den Berg 1982). A straight line can be fitted to the plot of [M]/[ML] versus [M] with a slope of $1 / \mathrm{L}_{\text {TOт }}$ and an intercept at $1 / \mathrm{K}_{\mathrm{app}}$. The complexing capacity and apparent stability constant are valid only under the specific experimental conditions (Plavšić et al. 1982, Scoullos et al. 2006).

During the titrations every addition of metal ion to the sample solution was equilibrated $20 \mathrm{~min}$ and was measured 3 consecutive times. The reproducibility of the method for $\mathrm{L}_{\text {TOтCu }}$ and $\mathrm{L}_{\text {TOTCd }}$ is $\pm 2 \times 10^{-9} \mathrm{~mol}$ metal ion $\mathrm{l}^{-1}$. Fig. 1 illustrates the determination of the complexing capacity using the example of Skeletonema costatum. Fig. 1A presents results of the anodic stripping voltammetric waves for $\mathrm{Cu}$ ion titration, where increasing amounts of $\mathrm{Cu}$ ions (8 to $260 \mathrm{nmol}^{-1} \mathrm{Cu}$ ) were added to a diluted culture (1:5) of $S$. costatum. The voltammetric peak of $\mathrm{Cu}$ ions in the culture samples appears at ca. $-0.2 \mathrm{~V}$ (Fig. 1), which is characteristic for chloride solutions (seawater) in which oxido/reduction of $\mathrm{Cu}$ ions proceeds in 2 steps. First the $\mathrm{Cu}^{ \pm 0}$ is oxidized to $\mathrm{Cu}^{+0}$, and this is the visible peak described above. Thereafter, the $\mathrm{Cu}^{+0}$ is oxidized to $\mathrm{Cu}^{2+}$ at a more positive potential (ca. +0.05 V) (Krznarić et al. 1992), which coincides with the oxidation wave of the $\mathrm{Hg}$ of the mercury drop working electrode and is observed as steep slope in current at potentials greater than $0.1 \mathrm{~V}$ in Fig. 1.

In Fig. $1 \mathrm{~B}$, the concentration of the added $\mathrm{Cu}$ ions is depicted on the $\mathrm{x}$-axis versus the found (measured) $\mathrm{Cu}$ ion concentration for each addition of $\mathrm{Cu}$ to pure electrolyte $(0.55 \mathrm{M} \mathrm{NaCl})$ and to the Skeletonema costatum culture. Fig. $1 \mathrm{C}$ presents the linearization according to the Ružić-van den Berg method for the data in Fig. 1A,B.

Identification of $\mathrm{Fe}^{3+}$ complexes. SWV scans of laminarin, carrageenan and alginic acid solutions were made to identify the formation of Fe complexes with these model substances.

Determination of stability constants of $\mathrm{Fe}^{3+}$ complexes. The Fe binding strength to the model PS was investigated using CLE-CSV (Croot \& Johansson 2000). All work was carried out in a class 100 clean room, and all equipment was carefully acid washed. In short, each PS was dissolved in UV pre-treated organic-free seawater and titrated with Fe standard solutions (0.5 to $5 \mu \mathrm{M})$, which were prepared from a $10 \mathrm{mM} \mathrm{Fe}^{3+}$ stock solution prepared from $\mathrm{FeCl}_{3} \cdot 6 \mathrm{H}_{2} \mathrm{O}$ in $1 \% \mathrm{HCl}$ (Sigma, TraceSELECT Ultra). The portion of 'free' Fe not complexed by the PS but bound to the competing ligand 2-(2-thiazolylazo)-p-cresol (TAC) was measured. TAC is a Fe ligand of known strength added to the sample in a known concentration. Fe reaches an equilibrium distribution between the PS and TAC according to the concentration of each constituent and the stability constant of each
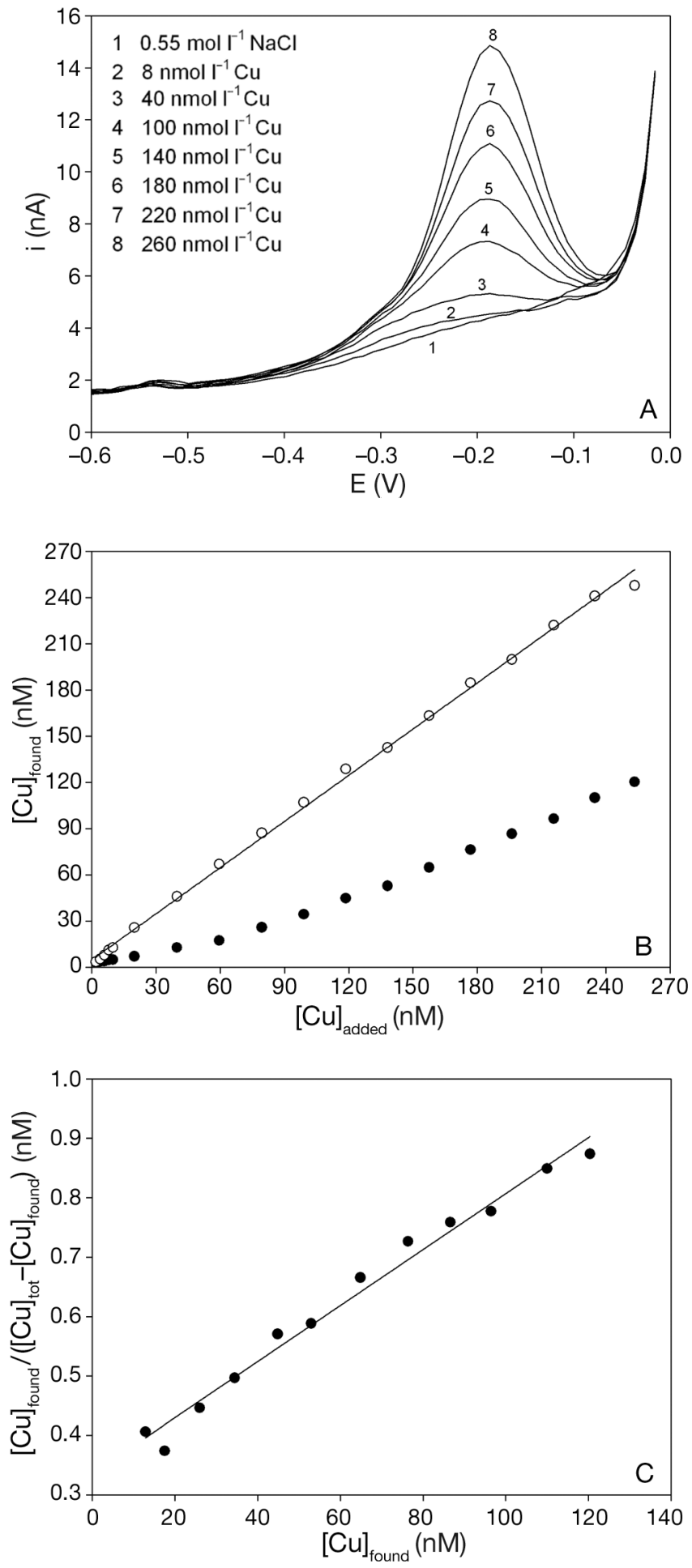

Fig. 1. Skeletonema costatum. Cu complexing capacity $(\mathrm{CuCC})$ for Skeletonema costatum (1:5 diluted). (A) Voltammograms of the additions of $\mathrm{Cu}$ ions to $0.55 \mathrm{M} \mathrm{NaCl}$. i (nA): oxidation current; E: electrode potential. (B) Data presented as concentrations of $\mathrm{Cu}$ ions added to $0.55 \mathrm{M} \mathrm{Na} \mathrm{Cl}$ (O) or S. costatum culture (๑) versus $\mathrm{Cu}$ ions found. (C) Results from $\mathrm{B}$ as free $\mathrm{Cu}$ ions found versus ( $\mathrm{Cu}$ ions found)/ (complexed $\mathrm{Cu}$ ions) 
complex. The Fe-TAC complex can be measured electrochemically, as it induces a current when reduced on the electrode, whereas the potentially formed Fe-PS complex cannot. This method has a detection window for the conditional stability constants $\left(\mathrm{K}^{\prime}\right)$ of competing Fe ligands depending on the concentration of added TAC (Gledhill \& van den Berg 1994). TAC concentration in our experiments was $10 \mu \mathrm{M}$, and the respective conditional stability constant ranged from $\log \mathrm{K}_{\mathrm{FeL}}^{\prime}=21.4$ to 23.4 .

The titration curve (i.e. added Fe versus reduction current) can be evaluated by fitting a nonlinear model of the competitive equilibrium in the solution, hence retrieving the values of the unknown parameters, i.e. the stability constant of the Fe-PS complex and the concentration of PS (Croot \& Johansson 2000).

Determination of reduced sulfur species (RSS). RSS were determined by square wave cathodic stripping voltammetry (SWCSV; Ciglenečki \& Ćosović 1996). Measurements were conducted directly after sample preparation and again after purging the $50 \mathrm{ml}$ solution with $\mathrm{N}_{2}$ gas to determine the fraction of RSS present as volatile RSS which are purgable.

After accumulation of RSS on the electrode surface at a deposition potential of $\mathrm{E}=-0.20 \mathrm{~V}$ (versus Ag/ $\mathrm{AgCl}$ ) from a stirred solution, we ran potential scans in the negative direction (up to $\mathrm{E}=-1.00 \mathrm{~V}$ versus $\mathrm{Ag} / \mathrm{AgCl}$ ), and $\mathrm{HgS}$ reduction peaks characteristic for RSS were recorded. Then, the solution was acidified ( $\mathrm{pH} 2.0$ ), purged with $\mathrm{N}_{2}$ and the $\mathrm{pH}$ readjusted back to $\mathrm{pH} 8.0$ and the RSS signal recorded again. The concentration of non-purgable sulfur species is determined after raising the $\mathrm{pH}$ back to $\mathrm{pH}$ 8.0. Samples were not readjusted to exactly the original $\mathrm{pH}$, because re-adjustment was done in the electrochemical cell, so approximate concentrations of either $\mathrm{HCl}$ or $\mathrm{NaOH}$ were added. As a consequence, the signal of RSS as seen in Fig. 4A\&B differed slightly in the position on potential scale.

RSS concentrations are expressed as equivalents of glutathione, determined from a calibration (from 0 to $200 \mathrm{nmol} \mathrm{l}^{-1}$ ) as appropriate for the concentration range observed in the cultures. Glutathione was chosen as the standard because of its electrochemical similarity with the sulfur species observed in the 3 cultures, i.e. the appearance of the half-wave potential and the behavior upon $\mathrm{pH}$ changes were similar (Ciglenečki \& Ćosović 1996). Furthermore, thiols/glutathione are known to be generated in phytoplankton cultures (Leal et al. 1999, Laglera \& van den Berg 2003, 2006).

Constant-current chronopotentiometric stripping analysis (CPSA) for the determination of catalytic groups. CPSA produces a well-resolved catalytic peak (so called peak ' $\mathrm{H}^{\prime}$ ) (Tomschik et al. 1998) that is char- acteristic for peptides and proteins at nanomolar concentrations (Ostatná et al. 2007). In CPSA the potential of the catalytic reaction peak (Ep) and its height $(\mathrm{dE} / \mathrm{dt})^{-1}$ depend primarily on the molecular structure, i.e. atoms or a group of atoms, their position in the molecule and their adsorbability onto the surface of the working electrode. Nitrogen, sulfur, phosphorus and oxygen are the key atoms in a molecule producing a catalytic peak. Molecules with free electron pairs, which attract hydrogen ions and are easily adsorbed onto the electrode surface, lower the hydrogen overpotential, i.e. hydrogen ions need less energy for the reduction and appear at more positive potentials. Accumulation of the catalytically active compound at potential $\mathrm{E}_{\mathrm{d}}=-0.20 \mathrm{~V}$ was achieved by stirring the solution for $t_{a}=60 \mathrm{~s}$ (accumulation time). After a quiescent period of $10 \mathrm{~s}$, a constant stripping current of $\mathrm{I}_{\text {str }}=$ $-1 \mu \mathrm{A}$ intensity was passed through the electrolytic circuit, and CPSA curves were recorded. This method has also proved suitable for the determination of N-polymers in seawater (Strmeãki et al. 2010).

Surface-active substances (SAS). SAS were determined with phase-sensitive alternating current voltammetry (AC) (Ćosović \& Vojvodić 1987, Vojvodić \& Ćosović 1996). This electrochemical method measures the capacitive current (i.e. the current arising from adsorption processes, measured out-of-phase with the applied potential) separately from the faradaic current (originating from redox processes, measured in-phase with the applied potential). Out-of-phase measurements have found wide application in the study of organic substances with surface-active properties in marine and freshwater systems (Ćosović 1985, Ćosović 2005). The measurement conditions were frequency of $75 \mathrm{~Hz}$, amplitude of $10 \mathrm{mV}$ and phase angle of $90^{\circ}$ so that only the capacitive component of the current was recorded versus the potential (E). In the presence of surface-active organic material, the decrease in the capacitive current below the value for the pure electrolyte solution at a chosen constant potential $\left(E_{d}=\right.$ $-0.6 \mathrm{~V}$ ) is a function of the amount of SAS adsorbed onto the electrode. The amount of SAS can be expressed quantitatively by an equivalent amount of a calibration substance, e.g. nonionic surfactant Triton$\mathrm{X}-100$. The nonionic surfactant Triton-X-100 proved to be a very good model substance used in many studies in seawater as well as in freshwater. This compound has been used as a model substance for SAS for more than 20 yr (Ćosović \& Vojvodić 1987, Vojvodić \& Ćosović 1996, Kujawinski et al. 2002, Croot et al. 2007, Gašparović et al. 2007, Plavšić et al. 2009), making our results comparable to earlier work. The potential $\mathrm{E}_{\mathrm{d}}=$ $-0.6 \mathrm{~V}$ is close to the potential of zero-charge of mercury in $0.55 \mathrm{M} \mathrm{NaCl}$, i.e. the adsorption of neutralhydrophobic molecules are favored. A $0.55 \mathrm{M} \mathrm{NaCl}$ 
solution is a perfect model for investigating the adsorption of SAS because it has the ionic strength of seawater but does not contain other constituents.

TEP determinations. TEP were analyzed colorimetrically (Passow \& Alldredge 1995). Six replicate samples of $50 \mathrm{ml}$ each were filtered onto $0.4 \mu \mathrm{m}$ polycarbonate filters (Poretics) and stained with Alcian blue. Gum Xanthan was used as a calibration standard, and results are expressed as Gum Xanthan equivalent per liter (GX equiv. $\mathrm{l}^{-1}$ ).

Carbohydrate determinations. Carbohydrates (PS + MS) were determined for the whole sample (dissolved + particulate fraction) and for the dissolved fraction $(<0.4 \mu \mathrm{m})$ (Myklestad et al. 1997). This method, which measures both neutral and charged carbohydrates, subjects the saccharides to an oxidation reaction at alkaline $\mathrm{pH}$, during which $\mathrm{Fe}^{3+}$ is reduced to $\mathrm{Fe}^{2+}$. The $\mathrm{Fe}^{2+}$ is then determined colorimetrically after condensation with the cromogen 2,4,6-tripyridyl-s-triazine (TPTZ) and formation of the purple color of $\mathrm{Fe}$ $(\mathrm{TPTZ})_{2}{ }^{2+}$. The calibration is done with glucose, and results are expressed as glucose equivalents. Samples between 10 and $20 \mathrm{ml}$ each were filtered through a $0.4 \mu \mathrm{m}$ (PC, Poretics) filter for the determinations of dissolved carbohydrates. Total (dissolved + particulate) and dissolved MS were determined in triplicate $1 \mathrm{ml}$ samples of unfiltered and $0.4 \mu \mathrm{m}$ filtered samples, respectively. The total carbohydrate content was measured in $4 \mathrm{ml}$ of filtered and unfiltered sample after hydrolysis by adding $0.4 \mathrm{ml} 1 \mathrm{M} \mathrm{HCl}$ and heating up to $150^{\circ} \mathrm{C}$ for $1 \mathrm{~h}$ in sealed glass ampoules. The PS concentration was determined by subtracting the MS concentration from the total carbohydrate concentration.

\section{RESULTS AND DISCUSSION}

\section{Complexing capacity and stability constant for $\mathrm{Cu}$ and $\mathrm{Cd}$}

The complexing capacity of a metal equals the total concentration of ligands that form complexes with that metal in a sample. In Table 1 the results of the complexing capacity measurements for $\mathrm{L}_{\text {TOTCu }}$ and $\mathrm{L}_{\text {TOTCd }}$ for the 3 phytoplankton cultures and the model compounds are presented. The Ružić-van den Berg method is suitable as it calculates $\mathrm{L}_{\text {TOT }}$ from the whole titration curve, even when full saturation of the binding sites is not achieved. All the data points on the curve have the same weight in the calculation of $\mathrm{L}_{\text {TOT. }}$. When the inert complex is present in the solution, it does not dissociate during the measurement (i.e. the chosen stirring rate in DPASV), so only free metal ions diffuse to the electrode surface to form an amalgam. This eliminates any problem caused by different diffusion coefficients of the metal ion and metal complex. It is possible that apparent complexing capacity can be reduced by adsorption of the organic ligand on the electrode surface. This would result from a different sensitivity for the metal ion in the $0.55 \mathrm{M} \mathrm{NaCl}$ solution with added ligand (Plavšić et al. 2006). By applying pseudopolarography, the half-wave potentials for inert organic complexes, both for model ligands and for natural samples (Croot et al. 1999, Tsang et al. 2006), can be determined. Originally developed for the calculation of stability constants for labile complexes (Branica et al. 1977), pseudopolarography has also been used in recent years (Croot et al. 1999, Tsang et al. 2006) for

Table 1. Apparent complexing capacity $(\mathrm{CC})$ for copper $(\mathrm{Cu})$ and cadmium $(\mathrm{Cd})$ ions, and characteristics of organic matter in cultures of Skeletonema costatum, Thalassiosira weissflogii, Emiliania huxleyi and model polysaccharides. $\mathrm{Cu}_{\mathrm{T}}$, $\mathrm{Cd}_{\mathrm{T}}$ : total concentration of copper, or cadmium; $\mathrm{K}_{\mathrm{app}}$ : apparent stability constant; SAS: surface-active substances; CPSA: Constant-current chronopotentiometric stripping analysis of catalytic effect; GSSG: Glutathione; (-) not measured; blank cells: value was below detection limit. Repeated measurements in the past have given a standard deviation of $5 \%$ for these electrochemical measurements (Ciglenečki \& Cosović 1996)

\begin{tabular}{|c|c|c|c|c|c|c|c|c|c|}
\hline Samples & $\begin{array}{l}\mathrm{Cu}_{\mathrm{T}} \\
(\mathrm{nM})\end{array}$ & $\begin{array}{c}\mathrm{CuCC} \\
(\mu \mathrm{M})\end{array}$ & $\log \mathrm{K}_{\mathrm{app} \mathrm{Cu}}$ & $\begin{array}{l}\mathrm{Cd}_{\mathrm{T}} \\
(\mathrm{nM})\end{array}$ & $\begin{array}{l}\mathrm{CdCC} \\
(\mu \mathrm{M})\end{array}$ & $\log K_{\text {app Cd }}$ & $\begin{array}{c}\text { SAS } \\
\text { (mg } \mathrm{l}^{-1} \text { equiv. } \\
\text { Triton-X-100) }\end{array}$ & CPSA & $\begin{array}{c}\text { Sulfur } \\
\text { (as equiv. } \\
\text { GSSG nM) }\end{array}$ \\
\hline S. costatum & 23.80 & 1.06 & 6.45 & 16.45 & 0.022 & 8.73 & 0.24 & Yes & 74 \\
\hline T. weissflogii & 26.60 & 1.14 & 6.18 & 14.85 & 0.020 & 8.83 & 0.18 & No & 202 \\
\hline E. huxleyi & 16.21 & 0.14 & 7.25 & 12.59 & 0.043 & 7.28 & 0.26 & No & 50 \\
\hline $\begin{array}{c}\text { 1-carrageenan } \\
\left(10 \mathrm{mg} \mathrm{l}^{-1}\right)\end{array}$ & & No & & & No & & 0.05 & Yes & - \\
\hline $\begin{array}{l}\text { Alginic acid } \\
\left(10 \mathrm{mg} \mathrm{l}^{-1}\right)\end{array}$ & & & No & & No & & 0.08 & No & - \\
\hline $\begin{array}{l}\text { Laminarin } \\
\qquad\left(10 \mathrm{mg} \mathrm{l}^{-1}\right)\end{array}$ & & No & & & No & & 0.32 & No & - \\
\hline $\begin{array}{l}\text { Phytagel } \\
\left(5 \mathrm{mg} \mathrm{l}^{-1}\right) \text { total }\end{array}$ & 3.86 & 0.330 & 6.65 & 2.92 & 0.006 & 9.19 & 0.29 & No & - \\
\hline$<0.7 \mu \mathrm{m}$ & 1.83 & 0.093 & 7.38 & 1.13 & 0.004 & 8.70 & - & No & - \\
\hline$<0.2 \mu \mathrm{m}$ & 1.08 & 0.089 & 7.47 & 1.07 & 0.004 & 8.75 & 0.21 & No & - \\
\hline
\end{tabular}


inert complexes. For $\mathrm{Cu}$ complexes pseudopolarography yielded $\mathrm{E}^{\prime}{ }_{1 / 2}$ values from -0.35 to $-0.82 \mathrm{~V}$ for model ligands and $-0.66 \mathrm{~V}$ for Skeletonema costatum (Croot et al. 1999). The estimated $E_{1 / 2}^{\prime}$ for the natural inert complexes with $\mathrm{Cd}$ in freshwaters range from -1.45 to $-1.62 \mathrm{~V}$, while for selected model substances they range from -0.7 to $-1.3 \mathrm{~V}$ (Tsang et al. 2006). This implies that our chosen potentials for the accumulation of $\mathrm{Cu}(-0.6 \mathrm{~V})$ and $\mathrm{Cd}(-0.9 \mathrm{~V})$ complexes could have led to the underestimation of the complexing capacity, as possibly some complexes could have been reduced, increasing the concentration of the labile metal ions. Calculations of complexing capacities are operationally defined and only valid for the chosen conditions.

The complexing capacity for $\mathrm{Cu}$ ions was the highest in Thalassiosira weissflogii $(1.14 \mu \mathrm{M})$ and Skeletonema costatum $(1.06 \mu \mathrm{M})$ while it was an order of magnitude lower $(0.14 \mu \mathrm{M})$ in the culture of Emiliana huxleyi. In E. huxleyi the complexing capacity for $\mathrm{Cd}$ ions was, however, twice that of $T$. weissflogii and S. costatum (0.04 vs. $0.02 \mu \mathrm{M}$ and $0.02 \mu \mathrm{M}$, respectively). Apprecia-

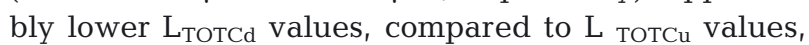
indicate fewer binding sites for $\mathrm{Cd}$ and are common (Scoullos et al. 2006). The geometrical distortion of $\mathrm{Cu}$ complexes due to the Jahn-Teller effect (Jahn \& Teller 1937) results in an energetic stabilization of the $\mathrm{Cu}$ complex. The smaller radius of the $\mathrm{Cu}$ ion compared to Cd (0.87 ̊̊ vs. $1.09 \AA$ ) may further promote Cu-ligand binding compared to Cd-ligand binding.

Complexing capacities for both $\mathrm{Cu}$ and $\mathrm{Cd}$ were lower in the $5 \mathrm{mg} \mathrm{l}^{-1}$ phytagel solution than in those stemming from the cultures of Skeletonema costatum and Thalassiosira weisflogii. No complexing of $\mathrm{Cu}$ or $\mathrm{Cd}$ was observed in the other model substances, although carrageenans and alginic acid have been shown to bind $\mathrm{Pb}, \mathrm{Cd}$ and $\mathrm{Zn}$ ions (Gimenez et al. 1995, Kim et al. 1995) as well as ${ }^{234}$ Th (Quigley et al. 2002).

Stability constants for both $\mathrm{Cu}$ and $\mathrm{Cd}$ (Table 1) were $\log \mathrm{K}_{\mathrm{appCu}, \mathrm{Cd}}=6$ to 9. The apparent stability constants for $\mathrm{Cd}$ were higher than those for $\mathrm{Cu}$, indicating stronger binding of $\mathrm{Cd}$ ions. Higher concentrations of ligands imply a lower average $\log \mathrm{K}_{\mathrm{app}}$, but some fraction of the $\mathrm{Cu}$ may, nevertheless, be complexed more strongly than some of the $\mathrm{Cd}$. It is also important to note that results of electrochemical methods are dependant on the conditions applied during measurements (e.g. stirring rate in ASV or competing ligand in CSV) (concept of the detection window) (Plavšić et al. 1982, van den Berg et al. 1990, Buck \& Bruland 2005), and measured $\mathrm{K}_{\mathrm{app}}$ and $\mathrm{L}_{\mathrm{TOT}}$ for $\mathrm{Cu}$ and $\mathrm{Cd}$ could differ if different measurement conditions are chosen.

Some details on binding characteristics may be derived from size fractionation experiments. A $\mathrm{L}_{\text {TотCu }}$ of $0.33 \mu \mathrm{M}$ was obtained for the unfiltered phytagel solution (Table 1), whereas the $\mathrm{L}_{\text {TотCu }}$ after filtration through either $0.2 \mu \mathrm{m}$ or $0.7 \mu \mathrm{m}$ was $73 \%$ lower at $0.09 \mu \mathrm{M}$, suggesting that the binding of $\mathrm{Cu}$ was mostly with the particulate fraction $>0.7 \mu \mathrm{m}$ of the gel solution. The surface-area-to-volume ratio of hydrogels is smaller in the larger size fraction. The much higher $\mathrm{L}_{\text {Tотсu }}$ in the unfiltered solution thus suggests that $\mathrm{Cu}$ binding sites were primarily located at the inner surface of the gels. The binding sites may be fairly nonspecific, explaining the low stability constant.

In contrast, the $\mathrm{L}_{\text {TOTCd }}$ was reduced by only $33 \%$ in the phytagel solution after filtration (by either $0.2 \mu \mathrm{m}$ or $0.7 \mu \mathrm{m})$. The precision of the method is high enough to allow the quantification of this reduction in the

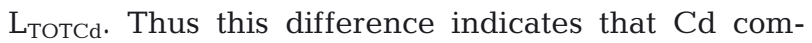
plexed mostly with material small enough to pass a $0.2 \mu \mathrm{m}$ filter. The larger size of the Cd ion, compared to the $\mathrm{Cu}$ ion, in combination with the same charge and a stable electronic structure would make the sites on the larger surface area (after filtration) less restricted by steric factors and more available for Cd binding. Interestingly, L $\mathrm{L}_{\mathrm{TOTCd}}$ was positively correlated with MS concentration while the same was not true for $\mathrm{L}_{\mathrm{TOTCu}}$. MS are less likely than PS to form large gel-particles retainable by filters.

\section{Identification of $\mathrm{Fe}^{3+}$ complexes with laminarin, carrageenan and alginic acid}

The position of the half-wave potential of reduction is characteristic for a specific metal ion, and a peak at the potential of approximately $-1.4 \mathrm{~V}$ is an indication of the presence of dissolved reducible Fe (presumably $\mathrm{Fe}^{2+} \rightarrow$ $\mathrm{Fe}^{ \pm 0}$ ). Calibration scans performed in artificial seawater containing $0.5 \mathrm{mM}$ BisTris buffer $(\mathrm{pH}$ 8) revealed a peak at $-1.4 \mathrm{~V}$ which increased linearly (Fig. 2A) with increasing Fe concentration (0 to $15 \mu \mathrm{M})$. The sensitivity was $1.4 \mathrm{nA} \mu \mathrm{M}^{-1}$. Apart from buffering the $\mathrm{pH}$, BisTris buffer also slightly complexes Fe and prevents hydrolysis and precipitation of $\mathrm{Fe}^{3+}$ (Taylor et al. 1994) even in its colloidal form (Schneider \& Schwyn 1987).

SWV scans (Fig. 2B) of laminarin $\left(2 \mathrm{~g} \mathrm{l}^{-1}\right)$, alginic acid $\left(2 \mathrm{~g} \mathrm{l}^{-1}\right)$ and carrageenan $\left(0.1 \mathrm{~g} \mathrm{l}^{-1}\right)$ (in $0.55 \mathrm{M} \mathrm{NaCl}$ at $\mathrm{pH} 8$ ) showed no peak around $-1.4 \mathrm{~V}$, indicating that there was no dissolved Fe species present that could be reduced. At a pH between 4 and 8, carrageenan $(0.1 \mathrm{~g}$ $\mathrm{l}^{-1}$ ) showed spike-like peaks at -0.5 and $-0.75 \mathrm{~V}$ (Fig. 2B) which reflect the sulfur contained in the side chains of this PS (Plavšić \& Ćosović 1998). Alginic acid also showed 2 peaks, 1 at ca. $-0.2 \mathrm{~V}$ (unidentified) and 1 at $-0.7 \mathrm{~V}$ (considering the spike-like shape probably caused by sulfur species). Rickard et al. (1999) report the reduction peak of $\mathrm{Fe}^{3+}$ at a potential of $-0.2 \mathrm{~V}$, but as this peak is absent in the voltammograms of the carrageenan and laminarin solutions, which were also 

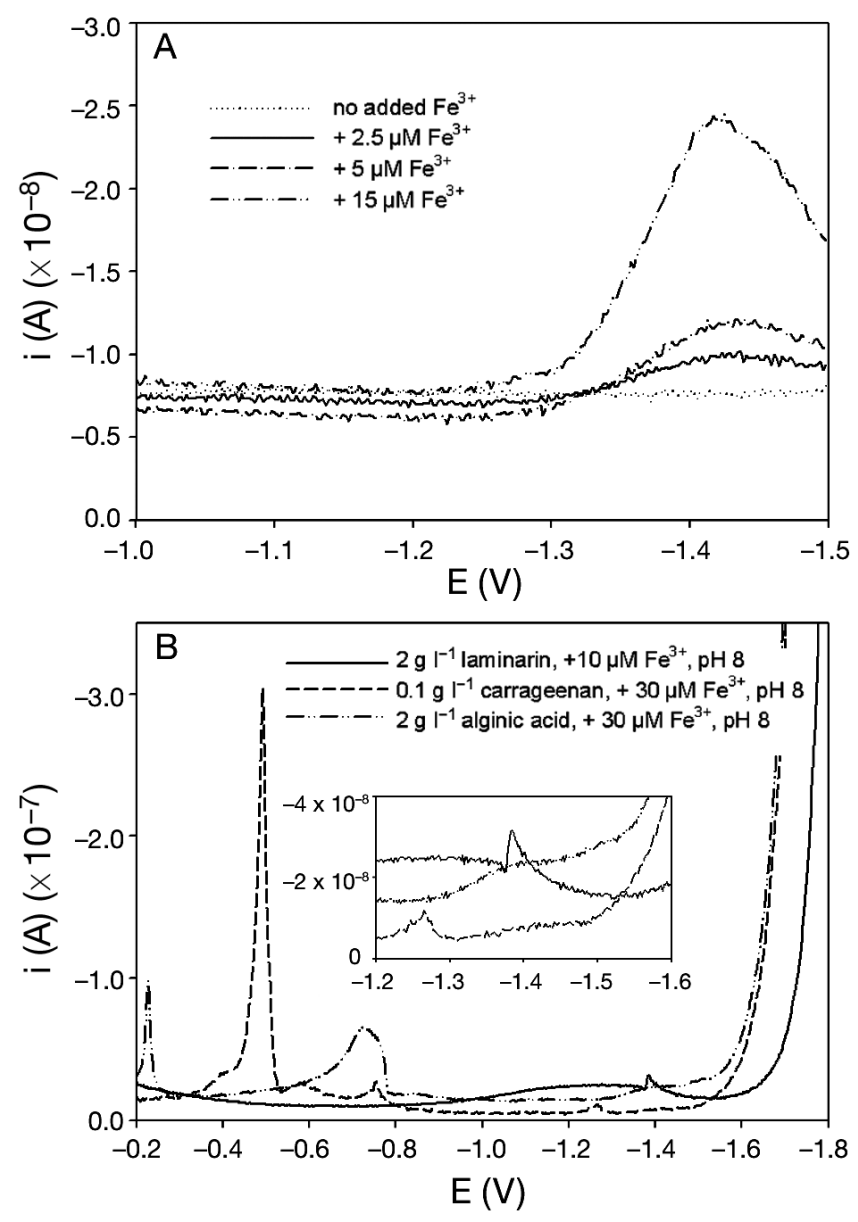

Fig. 2. Square wave voltammograms. (A) $\mathrm{Fe}^{3+}$ additions to a $0.5 \mathrm{mM}$ BisTris solution in artificial seawater at pH 8. (B) Scans of solutions of polysaccharides in artificial seawater at $\mathrm{pH} 8,10$ to $30 \mu \mathrm{M} \mathrm{Fe}{ }^{3+}$ added. Inset: detailed view of the potential range, -1.2 to $-1.6 \mathrm{~V}$, where peaks of Fe species are expected. i (A): oxidation curent; E: electrode potential

spiked with $\mathrm{Fe}^{3+}$ (30 and $10 \mu \mathrm{M}$ respectively), it is more likely to be caused by impurities in the alginic acid. The steep increase after -1.6 to $-1.7 \mathrm{~V}$ (Fig. 2B) is due to the hydrolytic formation of $\mathrm{H}_{2}$ and further on the reduction of sodium ions from supporting electrolyte on the mercury drop electrode.

\section{Determination of stability constants of $\mathrm{Fe}^{3+}$ complexes}

The Fe titration with laminarin, carrageenan and alginic acid using CLE-CSV over a range of 0.02 to $0.5 \mathrm{mg} \mathrm{l}^{-1}$ did not show a curvature (Fig. 3) and, consequently, no stability constant could be determined. Reducing the TAC concentration by $50 \%$ to $5 \mu \mathrm{M}$, to lower the detection window and shift the equilibrium more towards the Fe-PS complex, gave very similar results; slopes were generally lower (Fig. 3) than those of the reference sample (UV treated organic-free seawater). Thus the titrations of PS solutions of up to $0.5 \mathrm{mg} \mathrm{l}^{-1}$ did not yield any $\mathrm{K}^{\prime}$ values $\left(\mathrm{K}^{\prime}\right.$ is the conditional stability constant for FeL with respect to free $\mathrm{Fe}^{3+}$ ), indicating that these model PS bind Fe only weakly $\left(\log \mathrm{K}^{\prime}<21.4\right)$ if at all. This is in accordance with the result that these PS did not show any specific Fe(III) complexation and contrasts with results from Quigley et al. (2002), who showed enhanced Fe and Cd binding in organic matter enriched in the PS fraction compared to non-enriched material. These different results may reflect differences in the composition of exudates and organic matter. Alternatively, the inability to determine $\mathrm{K}^{\prime}$ values for our model substances may have been due to methodological problems. Contamination of the analysed substances with Fe seems unlikely. Bound Fe should result in a FeTAC peak after initial equilibration with TAC, because TAC is a strong Fe chelator and would strip at least some Fe off the potentially contaminated PS. This was not observed. The linear increase in labile Fe makes a decreased sensitivity due to PS adsorption onto the surface of the working electrode much more plausible than an incomplete titration of the PS.

We did not attempt to measure the apparent stability constant of $\mathrm{Fe}$ in phytoplankton exudates because of this lack of success with the model substances.

\section{Characterization of the organic matter}

\section{Concentrations of sulfur species}

All 3 cultures contained different concentrations of sulfur (Table 1); the highest concentrations by far

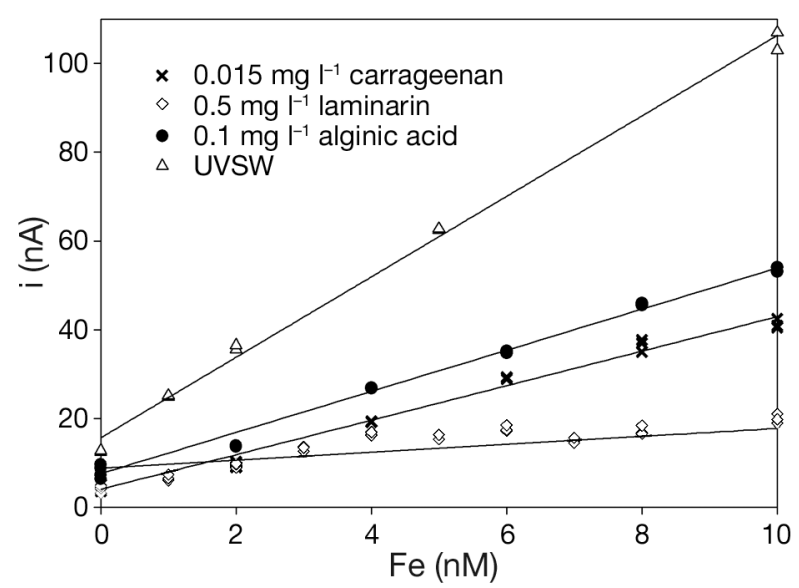

Fig. 3. Competitive ligand exchange cathodic stripping voltammetry (CLE-CSV) data of laminarin, carrageenan and alginic acid titrated with $\mathrm{Fe}^{3+}$. UVSW: UV irradiated seawater, i (nA): oxidation curent 
were in Thalassiosira weissflogii. A significant fraction of the RSS in this culture must have been present as sulfides, as indicated by the fact that an appreciable fraction of the sulfur was purged with $\mathrm{N}_{2}$ gas. The SWCSV for $T$. weissflogii was almost halved upon acidification, purging with $\mathrm{N}_{2}$ and readjustment of the $\mathrm{pH}$ (Fig. 4A). The original SWCSV for the Skeletonema costatum (Fig. 4B) remained the same upon acidification to $\mathrm{pH} 2$, purging with $\mathrm{N}_{2}$, and readjustment of $\mathrm{pH}$ back to 8.1, indicating the absence of sulfur species that could be purged by $\mathrm{N}_{2}$ gas. Emiliana huxleyi (not shown) behaved in a manner similar to that of $S$. costatum, also suggesting the absence of purgable sulfur species. Assuming that about half of the sulfur in the T. weissflogii culture was purgable, the concentration of organic, non-purgable sulfur in T. weissflogii was higher than that of $S$. costatum and E. huxleyi. Exudation products of phytoplankton vary with species and phase (Myklestad 1974, Myklestad 1995).

The non-purgable sulfur species of all 3 cultures electrochemically resembled glutathione. Glutathione and other thiols are present in surface waters and are known to be released by phytoplankton, including Emiliana huxleyi (Dupont \& Ahner 2005) and Thalassiosira weissflogii (Tang et al. 2005) when exposed to elevated concentrations of $\mathrm{Cu}$ or $\mathrm{Cd}$. However, the presence of the more complexed ligands, i.e. phytochelatins, with the common formula $(\gamma \text {-Glu-Cys })_{n}$-Gly of which the tripeptide glutathione ( $\gamma$-Glu-Cys-Gly) is the simplest form cannot be excluded (Mehra \& Mulchandani 1995, Scarano \& Morelli 1996, Cruz et al. 2005). All thiols have peaks at a potential similar to that of glutathione (Luther et al. 1985, Luther \& Church 1988, Luther et al. 1990).

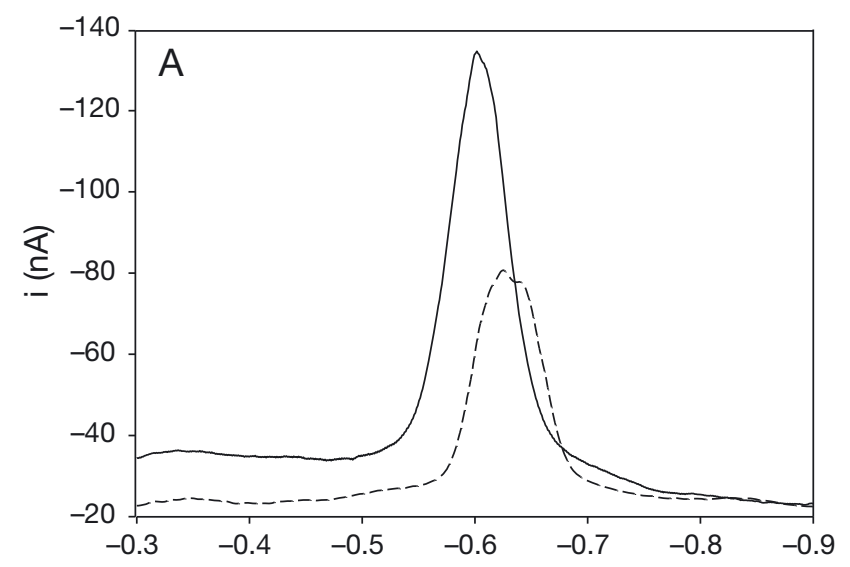

Presence of catalytic groups

Skeletonema costatum and the model substance t-carrageenan both exhibited the catalytic peak ' $\mathrm{H}$ ' (Strmečki et al. 2009, Strmečki et al. 2010) (Fig. 5, Table 1) obtained by prolonged accumulation (180 s and $300 \mathrm{~s}$ ) and situated at the potential of ca. $-1.7 \mathrm{~V}$. In the case of $\mathbf{l}$-carrageenan, this catalytic peak ' $\mathrm{H}$ ' is obtained because of catalytically active sulfate groups on PS (Strmečki et al. 2009). Protein-like complexing ligands, containing $\mathrm{N}$ atoms in the polymeric structure, could explain this observed peak ' $\mathrm{H}$ ' in $S$. costatum culture (Strmečki et al. 2010). Protein-like complexing ligands are abundant during $S$. costatum blooms (Lorenzo et al. 2007).

\section{Surface-active substances}

The characteristic 'AC out of phase voltammetric curves' reveal the suppression of the capacity current in comparison to the capacity current of the pure electrolyte (0.55 M NaCl) (Fig. 6, Table 1) and are the consequence of adsorption or desorption processes (Ćosović 1985). The pronounced peak (at approx. $\mathrm{E}=$ $-1.4 \mathrm{~V}$ ) recorded for phytagel means that the phytagel molecules were desorbed from the electrode. Other, smaller peaks could indicate reorganization of the adsorbed molecules on the electrode surface. The highest concentrations of SAS in the phytoplankton samples were observed in Emiliana huxleyi $\left(0.26 \mathrm{mg} \mathrm{l}^{-1}\right.$ equiv. Triton-X-100) and Skeletonema costatum (0.24 mg l-1 equiv. Triton-X-100) with lower values for Thalassiosira weissflogii (0.18 $\mathrm{mg} \mathrm{l}^{-1}$ equiv. Triton-X-100) (Table 1, Fig. 6). The SAS concentrations in E. huxleyi and $T$.

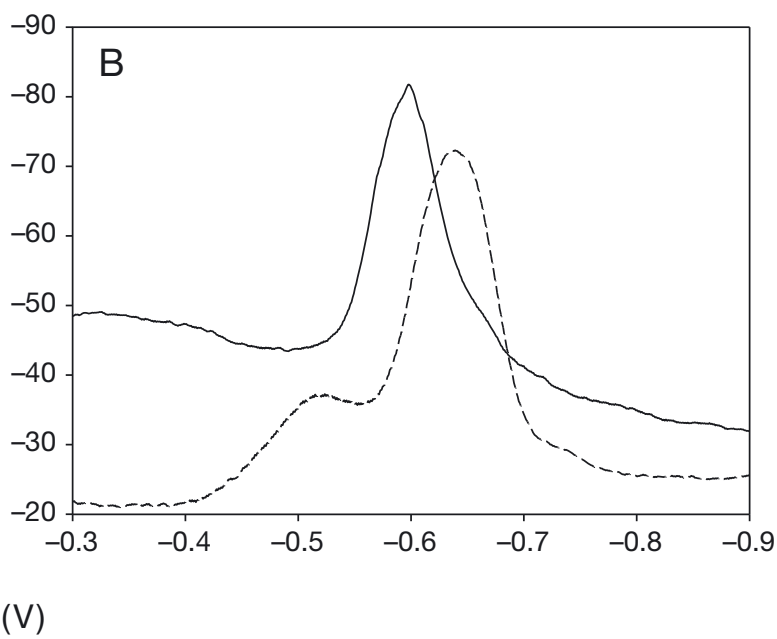

Fig. 4. Square wave voltammograms (SWV). (A) Thalassiosira weissflogii, (B) Skeletonema costatum at pH 8.1 (solid line) and after acidification, purging with $\mathrm{N}_{2}$ and readjustment of the $\mathrm{pH}$ back to $\sim 8.1$ (dashed line). i (nA): oxidation current; E: electrode po-

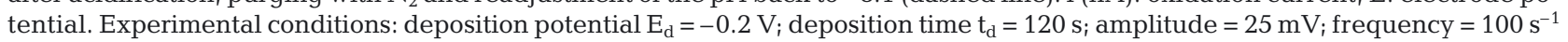




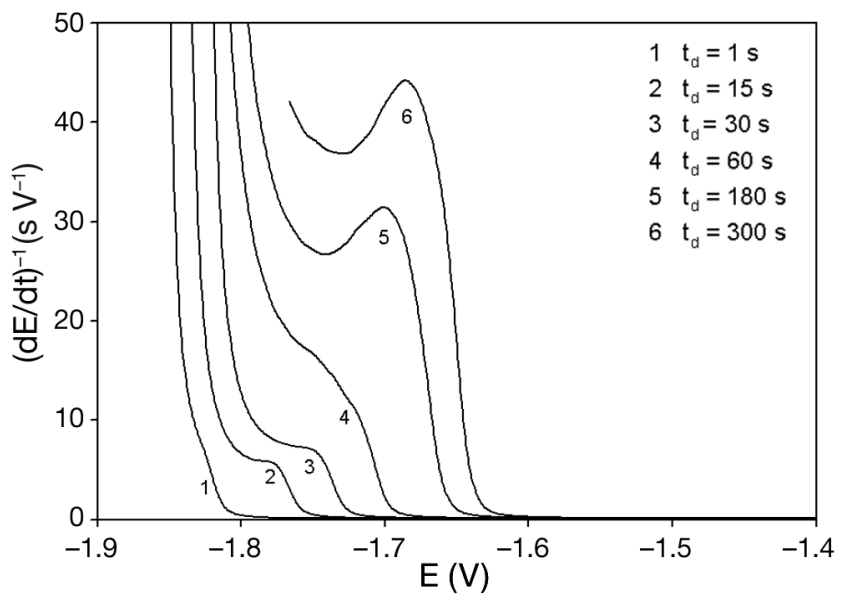

Fig. 5. Chronopotentiometric stripping analysis (CPSA) curves of Skeletonema costatum. E: electrode potential; t: time. Experimental conditions: deposition potential $\mathrm{E}_{\mathrm{d}}=-0.2$

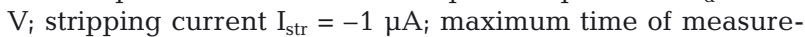
ment $=5 \mathrm{~s}$. Deposition times $\left(\mathrm{t}_{\mathrm{d}}\right)$ are indicated in the panel

weissflogii cultures are comparable to earlier measurements (Ciglenečki \& Ćosović 1996). SAS of $10 \mathrm{mg} \mathrm{l}^{-1}$ laminarin or $5 \mathrm{mg} \mathrm{l}^{-1}$ phytagel were considerably higher, whereas those of alginic acid and carrageenan were appreciably lower than those of the cultures (Table 1). In coastal regions, SAS are in the range 0.04 to $0.16 \mathrm{mg} \mathrm{l}^{-1}$ equiv. Triton-X-100 (Vojvodić \& Ćosović 1996, Plavšíc et al. 2009) and an order of magnitude smaller in the Southern Ocean (Croot et al. 2007). In situ SAS have been found elevated during the phytoplankton blooms (Croot et al. 2007) in the surface layer.

\section{TEP and carbohydrates}

The total (dissolved + particulate) carbohydrate (PS + MS) concentration ranged between 1.2 and $3.6 \mathrm{mg}$ glu-

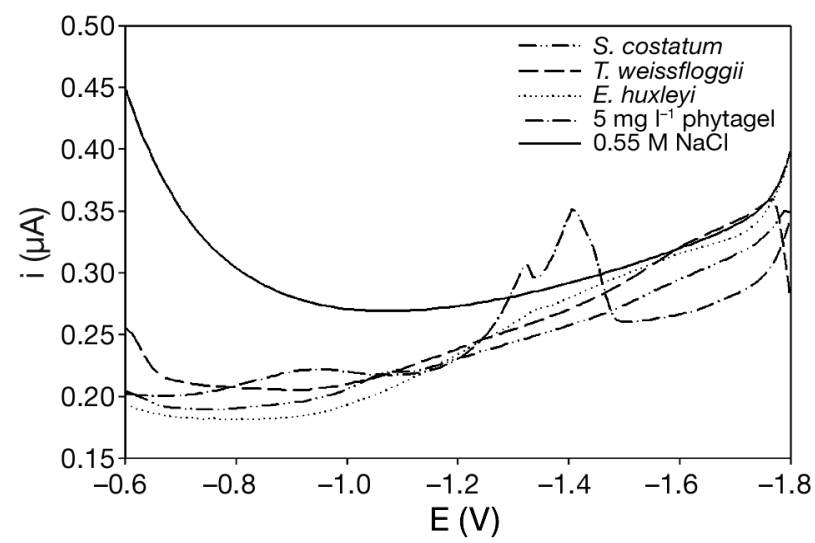

Fig. 6. Alternating current (AC)-voltammograms of phytoplankton cultures, phytagel $\left(5 \mathrm{mg} \mathrm{l}^{-1}\right)$ and a $0.55 \mathrm{M} \mathrm{NaCl}$ solution. i (nA): oxidation current; E: electrode potential. Experimental conditions: deposition potential $\mathrm{E}_{\mathrm{d}}=-0.6 \mathrm{~V}$; deposition time $t_{d}=60 \mathrm{~s}$; amplitude $=10 \mathrm{mV}$ cose equiv. $\mathrm{l}^{-1}$, of which $53,57,79$ and $98 \%$ belonged to the dissolved $(<0.4 \mu \mathrm{m})$ pool in phytagel, Thalassiosira weissflogii, Emiliana huxleyi and the Skeletonema costatum, respectively (Fig. 7). Less than $40 \%$ of the carbohydrates were PS in E. huxleyi and S. costatum, whereas PS dominated the carbohydrate pool in T. weissflogii (>60\%) and the phytagel solution $(>80 \%)$. PS concentrations ranged between 0.5 and $2.5 \mathrm{mg}$ glucose equiv. $\mathrm{l}^{-1}$ in the cultures and phytagel solution, with higher values in the unfiltered compared to the $0.4 \mu \mathrm{m}$ prefiltered samples (Fig. 7). Concentrations of dissolved PS were highest in T. weissflogii (1.3 mg glucose equiv. $\mathrm{l}^{-1}$ ), followed by $E$. huxleyi (0.8 $\mathrm{mg}$ glucose equiv. $\mathrm{l}^{-1}$ ) and $S$. costatum $(0.7 \mathrm{mg}$ glucose equiv. $\left.\mathrm{l}^{-1}\right)$ and lowest in phytagel (0.3 mg glucose equiv. $\mathrm{l}^{-1}$ ). Particulate PS were highest in T. weissflogii and phytagel and almost absent in S. costatum (Fig. 7).

TEP concentrations were highest in the phytagel solution (6.6 mg xanthan equiv. $\mathrm{l}^{-1}$ ), followed by Emiliana huxleyi (2.3 mg xanthan equiv. $\mathrm{l}^{-1}$ ) and Thalassiosira weissflogii (1.0 mg xanthan equiv. $\mathrm{l}^{-1}$ ) with the lowest concentration in culture media of Skeletonema costatum (0.4 mg xanthan equiv. $\mathrm{l}^{-1}$ ). TEP concentration reflected neither the pattern of particulate PS, nor that of SAS (Fig. 7).

\section{Comparison of dissolved organic matter in different samples}

TEP, SAS and RSS are substance classes that are operationally defined, and the exact chemical composition of each is unknown and variable. Most likely the compounds contributing to these classes overlap, meaning that some substances are members of more than one of these groups. As TEP consist largely of acidic PS, especially those rich in sulfur (Alldredge et al. 1993, Zhou et al. 1998), TEP most likely are SAS, and some TEP are also RSS, but many non-TEP substance classes belong to SAS and RSS. A direct comparison trying to assess the degree of overlap between these different measurements has never been made.

Our data suggest that TEP concentration was not correlated with carbohydrates, nor with SAS or sulfur concentrations. The lack of a correlation with PS confirms that the acidic PS making up TEP are a varying fraction of total PS. Additionally, the composition of TEP depends on the species generating TEP, and conversions to carbon (or glucose units) depend on TEP composition (Engel \& Passow 2001).

The lack of a correlation between TEP and SAS suggests that the fraction of substances belonging to both SAS and TEP is small or variable, although TEP are known to be sticky, to promote aggregation of particles (Passow 2002) and accumulate in the surface micro- 


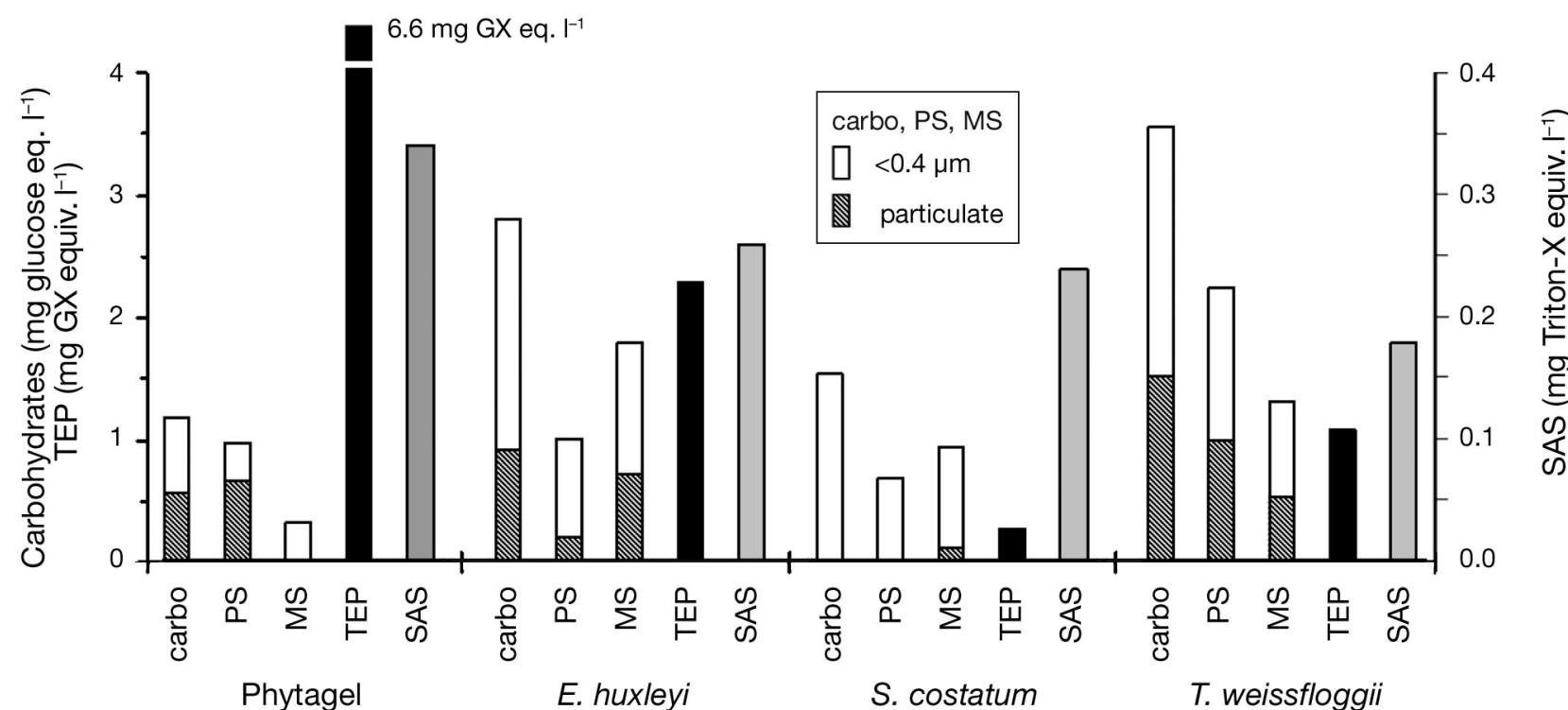

Fig. 7. Concentrations of particulate and dissolved carbohydrates (carbo = polysaccharides + monosaccharides), polysaccharides (PS), monosaccharides (MS), transparent exopolymer particles (TEP) and surface-active substances (SAS) in phytagel (5 mg $\mathrm{l}^{-1}$ ) and in cultures of Emiliana huxleyi, Skeletonema costatum and Thalassiosira weissflogii

layer (Wurl \& Holmes 2008). A similar lack of correlation between TEP and SAS has been observed in field samples also (unpubl. data). TEP can be rich in sulfur (Zhou et al. 1998), but our samples clearly contained other substance classes rich in sulfur as TEP and sulfur concentrations showed no correlation. The correlation between PS and sulfur (PS $<0.4 \mu \mathrm{m}: \mathrm{r}=0.94, \mathrm{p}<0.01$, $\mathrm{n}=3, \mathrm{PS}>0.4 \mu \mathrm{m}: \mathrm{r}=0.91, \mathrm{p}<0.05, \mathrm{n}=3$ ) implies that a significant fraction of the total amount of sulfur was associated with PS, which did not form TEP. Our data suggest that glutathione type substances contributed appreciably to the high sulfur content in our cultures.

SAS were inversely correlated both with dissolved PS ( $\mathrm{r}=0.96, \mathrm{p}<0.001, \mathrm{n}=4)$ and sulfur content $(\mathrm{r}=$ 0.99, $\mathrm{p}<0.0005, \mathrm{n}=3$ ), suggesting that SAS in our samples consisted of sulfur-poor substances other than PS. SAS generated by phytoplankton can be rich in proteinaceous substances (Gašparović et al. 2007).

Characteristics of the phytagel model solution were not evenly distributed between the fraction retained and the fraction passing through filters, emphasizing that TEP, SAS and carbohydrates measure different substance classes. Whereas $72 \%$ of the total SAS were found in the size fraction $<0.2 \mu \mathrm{m}$, only $53 \%$ of carbohydrates were in this size fraction, and TEP are, per definition, all retained on filters.

Characteristics of exudates of all 3 cultures differed appreciably, except for the presence of glutathione type substances in all 3 cultures. Thalassiosira weissflogii cultures contained large amounts of both purgable and non-purgable sulfur and high concentrations of PS (both dissolved and particulate), but relatively low TEP concentrations, whereas Skeletonema costatum was characterized by fairly high concentrations of non-purgable sulfur, and low concentrations of particulate carbohydrates (both PS and MS) and TEP. The presence of $\mathrm{NH}_{2}$ groups further characterized S. costatum exudates. Organic matter of Emiliana huxleyi was characterized by high concentrations of MS and relatively low sulfur content.

Relationship between complexing capacity and
dissolved organic matter characteristics

Assuming that the main respective $\mathrm{Cu}$ or $\mathrm{Cd}$ binding ligands in the phytoplankton exudates and model substances belonged to the same substance group and contributed significantly to that group, a relationship between the complexing capacity and the concentration of that substance group is expected.

Only $27 \%$ of the complexing capacity for $\mathrm{Cu}$ but $66 \%$ of that for Cd was retained in the $0.2 \mu \mathrm{m}$ filtrate of phytagel. SAS, which were retained to $72 \%$ in the $<0.2 \mu \mathrm{m}$ fraction, thus seemed to have not been directly responsible for the binding of $\mathrm{Cu}$, although some chemical specific component of SAS may have been. SAS may have been responsible for $\mathrm{Cd}$ complexing in the phytagel solution.

Characteristics of organic matter as described here varied between the different samples, and the complexing capacity of $\mathrm{Cu}$ or $\mathrm{Cd}$ showed no clear relationships to any of the types of ligands tested. TEP concentration was not correlated to the binding capacity or 
the stability constants for $\mathrm{Cu}$ or $\mathrm{Cd}$. SAS, another candidate for trace metal binding, were also not correlated to either $\mathrm{L}_{\mathrm{TOTCu}}$ or $\mathrm{L}_{\mathrm{TOTCd}}$. The apparent absence of significant amounts of ligands in TEP or SAS could have several explanations. Either no ligand of importance belonged to these groups of substances, or a potential ligand belonging to TEP or SAS made up only a small fraction of TEP or SAS, which was lost in the noise of the bulk measurement. Another possibility would be that a part of $\mathrm{Cu}$ or $\mathrm{Cd}$ complexes was directly reduced due to the applied potential range (see above). Or, metal ligands generated by the different phytoplankton species belonged to different substance classes. Carbohydrates (PS or MS) could also not explain the observed binding capacities of $\mathrm{Cu}$ or $\mathrm{Cd}$, except that the monosaccharide concentration was positively correlated to $\mathrm{L}_{\text {тотСи }}(\mathrm{MS}<0.4 \mu \mathrm{m}: \mathrm{r}=0.95, \mathrm{p}<0.005, \mathrm{n}=$ 4; $\mathrm{MS}>0.4 \mu \mathrm{m}: \mathrm{r}=0.85, \mathrm{p}<0.05, \mathrm{n}=4)$. This could indicate that MS were primarily responsible for the complexing capacity of Cd (although correlation does not imply causation). Cd has been detected mainly complexed to organic matter in the low molecular weight fraction $<1 \mathrm{kDa}$ (Wells et al. 1998, Grzybowski 2000), but there is no literature to support the claim that these ligands consist of MS.

A glutathione-type ligand that has been implicated as a Cu ligand (Al-Farawati \& van den Berg 1999, Leal et al. 1999, Laglera \& van den Berg 2003, Tang et al. 2005, Laglera \& van den Berg 2006, Marijić \& Raspor 2007) was found in all 3 cultures. About $50 \%$ of natural marine $\mathrm{Cu}$-complexing ligands have been found to belong to substances with a molecular weight between 1 and $10 \mathrm{kDa}$ (Wells et al. 1998, Wen et al. 1999) which corresponds with molecular mass of glutathione and phytochelatins. Assuming that about half of the sulfur in the culture of Thalassiosira weissflogii belonged to this ligand (RSS: T. weissflogii: 90 glutathione equiv. $\mathrm{nM}$, the other half was purgable), the concentration of organic, non-purgable sulfur was significantly ( $\mathrm{r}=$ 0.94, $\mathrm{p}<0.01, \mathrm{n}=3$ ) and positively correlated to $\mathrm{L}_{\mathrm{TOTCu}}$ suggesting that glutathione type ligand could have been responsible for the binding of $\mathrm{Cu}$ in all 3 cultures.

\section{SUMMARY}

The 3 phytoplankton cultures and the phytagel solution complexed $\mathrm{Cu}$ ions and to a lesser extent $\mathrm{Cd}$ ions. The apparent stability constants were higher for $\mathrm{Cd}$ ions than for $\mathrm{Cu}$. 'Glutathione type' ligands found in phytoplankton cultures are suggested to have been responsible for the binding of $\mathrm{Cu}$. We found no correlations between the complexing capacity, TEP, SAS and RSS in our samples, indicating that very different substance classes are measured with these respective methods, although all appear important for trace metal binding.

No complexation for $\mathrm{Fe}^{3+}$ was observed for laminarin, carrageenan and alginic acid. The slopes of the titration lines with Fe in the presence of these model compounds were decreased in comparison to the UV irradiated seawater, pointing to the fact that selected model compounds are strongly adsorbed and decrease the sensitivity of the Fe determination.

Clearly new approaches are needed to classify and characterize the marine ligands that drive trace metal cycling. The combination of radioisotope work with cross-flow ultrafiltration (Schlosser \& Croot 2008) is an example of a promising new approach.

Acknowledgements. The authors thank the Deutsche Forschungsgemeinschaft (DFG, KRO 436) for funding the collaboration between the Alfred Wegener Institute for Polar and Marine Research and the Ruđer Bošković Institute. M.P. and S.S. are also supported by the Croatian Ministry of Science, Education and Sport (Project no.: 098-0982934-2717: 'Nature of the organic matter, interaction with traces and surfaces in the environment') and U.P. and S.S. by the DFG (PA 424/6-2). We also thank Božena Cosović, Boris Koch and Oliver Lechtenfeld who commented on an earlier version of the manuscript. The authors appreciate very much the efforts and help of the Responsible Editor Ronald Kiene and 2 anonymous reviewers.

\section{LITERATURE CITED}

Al-Farawati R, van den Berg CMG (1999) Metal sulphide complexation in seawater. Mar Chem 63:331-352

Alldredge AL, Passow U, Logan BE (1993) The abundance and significance of a class of large, transparent organic particles in the ocean. Deep-Sea Res I 40:1131-1140

Aluwihare LI, Repeta DJ (1999) A comparison of the chemical characteristics of oceanic DOM and extracellular DOM produced by marine algae. Mar Ecol Prog Ser 186: 105-117

Benner R (2002) Chemical composition and reactivity. In: Hansell DA, Carlson C (eds) Biogeochemistry of dissolved organic matter. Academic Press, Elsevier Science, New York, NY, p 59-90

Bhaskar PV, Bhosle NB (2006) Bacterial extracellular polymeric substance (EPS): a carrier of heavy metals in the marine food-chain. Environ Int 32:191-198

> Blake AC, Chadwick DB, Zirino A, Rivera-Duarte I (2004) Spatial and temporal variations in copper speciation in San Diego Bay. Estuaries 27:437-447

Branica M, Novak DM, Bubić S (1977) Application of anodic stripping voltammetry to determination of the state of complexation of traces of metal ions at low concentration levels. Croat Chem Acta 49:539?547

Bruland KW (1992) Complexation of cadmium by natural organic ligands in the central North Pacific. Limnol Oceanogr 37:1008-1017

Bruland KW, Donat JR, Hutchins DA (1991) Interactive influence of bioactive trace metals on biological production in oceanic waters. Limnol Oceanogr 36:1555-1577

Buck K, Bruland KW (2005) Copper speciation in San Francisco Bay: a novel approach using multiple analytical windows. Mar Chem 96:185-198 
Ciglenečki I, Ćosović B (1996) Electrochemical study of sulfur species in seawater and marine phytoplankton cultures. Mar Chem 52:87-97

Ciglenečki I, Plavšić M, Vojvodić V, Ćosović B, Pepi M, Baldi F (2003) Evidence of mucopolysaccharide transformation by sulfide: comparisons between an enriched mixed benthic diatom culture and natural mucilage. Mar Ecol Prog Ser 263:17-27

Ćosović B (1985) Aqueous surface chemistry. Adsorption characteristics of organic solutes. Electrochemical evaluation. In: Stumm W (ed) Chemical processes in lakes. J. Wiley \& Sons, New York, NY, p 55-85

Ćosović B (2005) Surface active properties of the sea surface microlayer and consequences for pollution in the Mediterranean Sea. In: Saliot A (ed) The Mediterranean Sea. The Handbook of Environmental Chemistry Series, Springer, Berlin, p 269-297

C Ćosović B, Vojvodić V (1987) Direct determination of surface active substances in natural waters. Mar Chem 22: 363-373

Croot PL (2003) Seasonal cycle of copper speciation in Gullmar Fjord, Sweden. Limnol Oceanogr 48:764-776

> Croot PL, Johansson M (2000) Determination of iron speciation by cathodic stripping voltammetry in seawater using the competing ligand 2-(2-thiazolylazo)-p-cresol (TAC). Electroanalysis 12:565-576

> Croot PL, Laan P (2002) Continuous shipboard determination of $\mathrm{Fe}(\mathrm{II})$ in polar waters using flow injection analysis with chemiluminescence detection. Anal Chim Acta 466: 261-273

- Croot PL, Moffet JW, Luther GW (1999) Polarographic determination of half-wave potentials for copper-organic complexes in seawater. Mar Chem 67:219-232

Croot PL, Passow U, Assmy P, Jansen S, Strass VH (2007) Surface-active substances in the upper water column during a Southern Ocean Iron Fertilization Experiment (EIFEX). Geophys Res Lett 34:L03612. doi:10.1029/2006GL028080

Cruz BH, Diaz-Cruz JM, Arino C, Esteban M (2005) Complexation of heavy metals by phytochelatins: voltammetric study of the binding of $\mathrm{Cd}^{2+}$ and $\mathrm{Zn}^{2+}$ ions by the phytochelatin ( $\gamma$-Glu-Cys) $)_{3}$ Gly assisted by multivariate curve resolution. Environ Sci Technol 39:778-786

> Dryden CL, Gordon AS, Donat JR (2007) Seasonal survey of copper-complexing ligands and thiol compounds in a heavily utilized, urban estuary: Elizabeth River, Virginia. Mar Chem 103:276-288

Dupont CL, Ahner BA (2005) Effects of copper, cadmium and zinc on the production and exudation of thiols by Emiliania huxleyi. Limnol Oceanogr 50:508-515

Engel A, Passow U (2001) Carbon and nitrogen content of transparent exopolymer particles (TEP) in relation to their Alcian Blue adsorption. Mar Ecol Prog Ser 219:1-10

Gašparović B, Plavšić M, Bošković N, Ćosović B, Reigstad M (2007) Organic matter characterization in Barents Sea and eastern Arctic Ocean during summer. Mar Chem 105: 151-165

> Gimenez M, Arino C, Esteban M (1995) Voltammetry of $\mathrm{Pb}(\mathrm{II}), \mathrm{Cd}(\mathrm{II})$ and $\mathrm{Zn}$ (II) ions in the presence of sulfated polysaccharide $\lambda$-carrageenan. Anal Chim Acta 310: 121-129

Gledhill M, van den Berg CMG (1994) Determination of complexation of iron(III) with natural organic complexing ligands in seawater using cathodic stripping voltammetry. Mar Chem 47:41-54

Grzybowski W (2000) Comparison between stability constants of cadmium and lead complexes with humic substances of different molecular weight isolated from Baltic
Sea water. Oceanologia 42:473-482

Guillard RRL, Ryther JH (1962) Studies of marine planktonic diatoms. I. Cyclotella nana Hustedt and Detonula confervacea Cleve. Can J Microbiol 8:229-239

Guo L, Hung CC, Santschi PH, Walsh ID (2002) ${ }^{234}$ Th scavenging and its relationship to acid polysaccharide abundance in the Gulf of Mexico. Mar Chem 78:103-119

Honeyman B, Santschi P (1991) Coupling adsorption and particle aggregation: laboratory studies of 'colloidal pumping' using ${ }^{59} \mathrm{Fe}$-labeled hematite. Environ Sci Technol 25: 1739-1747

Jahn H, Teller E (1937) Stability of polyatomic molecules in degenerate electronic states. I. Orbital degeneracy. Proc R Soc Lond Series A, Mathematical and Physical Sci (1934-1990) 161:220-235

Kim Y, Yoo Y, Lee H (1995) Characteristics of lead adsorption by Undaria pinnatifida. Biotechnol Lett 17:345-350

> Krznarić D, Plavšić M, Ćosović B (1992) Voltammetric investigations of copper processes in the presence of oxygen. Electroanalysis 4:143-150

Kujawinski EB, Farrington JW, Moffet JW (2002) Evidence for grazing-mediated production of dissolved surface-active material by marine protists. Mar Chem 77:133-142

Laglera LM, van den Berg CMG (2003) Copper complexation by thiol compounds in estuarine waters. Mar Chem 82: 71-89

> Laglera LM, van den Berg CMG (2006) Photochemical oxidation of thiols and copper complexing ligands in estuarine waters. Mar Chem 101:130-140

Leal MFC, Vasconselos MTSD, van den Berg CMG (1999) Copper-induced release of complexing ligands similar to thiols by Emiliania huxleyi in seawater cultures. Limnol Oceanogr 47:1750-1762

Liss PS, Duce RA (1997) The sea surface and global change. Cambridge University Press, Cambridge

> Lorenzo JI, Nieto-Cid M, Alvarez-Salgado XA, Perez P, Beiras $\mathrm{R}$ (2007) Contrasting complexing capacity of dissolved organic matter produced during the onset, development and decay of a simulated bloom of the marine diatom Skeletonema costatum. Mar Chem 103:61-75

> Luther GW III, Church TM (1988) Seasonal cycling of sulfur and iron in porewaters of Delaware salt marsh. Mar Chem 23:295-309

Luther GW III, Giblin EA, Varsolona R (1985) Polarographic analysis of sulfur species in marine porewaters. Limnol Oceanogr 30:727-736

Luther GW III, Catalano G, De Lange GJ, Woittiey JRW (1990) Reduced sulfur in hypersaline anoxic basins in the Mediterranean Sea. Mar Chem 31:137-152

Mari X, Mignon C, Nicolas E (2009) Reactivity of transparent exopolymeric particles: a key parameter of trace metal cycling in the lagoon of Nouméa, New Caledonia. Mar Pollut Bull 58:1874-1879

Marijić VF, Raspor B (2007) Metallothionein in intestine of red mullet, Mullus barbatus as a biomarker of copper exposure in coastal marine areas. Mar Pollut Bull 54:935-940

Mehra RK, Mulchandani P (1995) Glutathione-mediated transfer of $\mathrm{Cu}(\mathrm{I})$ into phytochelatins. Biochem J 307 : $697-705$

Mopper K, Zhou J, Ramana KS, Passow U, Dam HG, Drapeau DT (1995) The role of surface-active carbohydrates in the flocculation of a diatom bloom in a mesocosm. Deep-Sea Res II 42:47-73

Muller FLL, Jacquet SP, Wilson WH (2003) Biological factors regulating the chemical speciation of $\mathrm{Cu}, \mathrm{Zn}$, and $\mathrm{Mn}$ under different nutrient regimes in a marine mesocosm experiment. Limnol Oceanogr 48:2289-2302 
Myklestad SM (1974) Production of carbohydrates by marine planktonic diatoms. I. Comparison of nine different species in culture. J Exp Mar Biol Ecol 15:261-274

Myklestad SM (1995) Release of extracellular products by phytoplankton with special emphasis on polysaccharides. Sci Total Environ 165:155-164

- Myklestad SM, Skanoy E, Hestmann S (1997) A sensitive and rapid method for analysis of dissolved mono- and polysaccharides in seawater. Mar Chem 56:279-286

> Ostatná V, Uslu B, Dogan B, Ozkan S, Paleček E (2006) Native and denatured bovine serum albumin. D.c. polarography, stripping voltammetry and constant current chronopotentiometry. J Electroanal Chem 593:172-178

> Passow U (2002) Transparent exopolymer particles (TEP) in aquatic environments. Prog Oceanogr 55:287-333

Passow U, Alldredge AL (1995) A dye-binding assay for the spectrophotometric measurement of transparent exopolymer particles (TEP). Limnol Oceanogr 40:1326-1335

Passow U, Dunne J, Murray JW, Balistrieri LS, Alldredge AL (2006) Organic carbon to ${ }^{234} \mathrm{Th}$ ratios of marine organic matter. Mar Chem 100:323-336

Plavšić M, Ćosović B (1998) Adsorptions of carrageenans on mercury surface in sodium chloride solution and seawater. Croat Chem Acta 72:233-243

> Plavšić M, Krznarić D, Branica M (1982) Determination of the apparent copper complexing capacity of seawater by anodic stripping voltammetry. Mar Chem 11:17-31

Plavšić M, Lee C, Cosović B, Lee C (2006) Copper complexing properties of melanoidins and marine humic material. Sci Total Environ 366:310-319

Plavšić M, Gašparović B, Strmečki S, Vojvodić V, Tepić N (2009) Copper complexing ligands and organic matter characterization in the northern Adriatic Sea. Estuar Coast Shelf Sci 85:299-306

Quigley MS, Santschi PH, Guo L, Honeyman BD (2001) Sorption irreversibility and coagulation behavior of ${ }^{234} \mathrm{Th}$ with marine organic matter. Mar Chem 76:27-45

Quigley MS, Santschi PH, Hung CC, Guo L, Honeyman BD (2002) Importance of acid polysaccharides for ${ }^{234} \mathrm{Th}$ complexation to marine organic matter. Limnol Oceanogr 47 : 367-377

Rickard D, Oldroyd A, Cramp A (1999) Voltammetric evidence for soluble $\mathrm{FeS}$ complexes in anoxic estuarine muds. Estuaries 22:693-701

Ross ARS, Ikonomou MG, Orians KJ (2003) Characterization of copper complexing ligands in seawater using immobilized copper (II)-ion affinity chromatography and electrospray ionization mass spectrometry. Mar Chem 83:47-58

Ružić I (1982) Theoretical aspects of the direct titration of natural waters and its information yield for trace metal speciation. Anal Chim Acta 140:99-113

Santschi PH, Murray JW, Baskaran M, Benitez-Nelson CR and others (2006) Thorium speciation in seawater. Mar Chem 100:250-268

Scarano G, Morelli E (1996) Determination of phytochelatins by cathodic stripping voltammetry in the presence of copper (II). Anal Chim Acta 319:13-18

Schlosser C, Croot PL (2008) Application of cross-flow filtration for determining the solubility of iron species in open ocean seawater. Limnol Oceanogr Methods 6:630-642

Schneider W, Schwyn B (1987) The hydrolysis of iron in synthetic, biological and aquatic media. In: Stumm W (ed) Aquatic surface chemistry: chemical processes at particlewater interface. John Wiley \& Sons, New York, NY, p 167-196

Editorial responsibility: Ronald Kiene, Mobile, Alabama, USA
Scoullos M, Plavšić M, Karavoltsos S, Sakellari A (2006) Partitioning and distribution of dissolved copper, cadmium and organic matter in Mediterranean marine coastal areas: the case of a mucilage event. Estuar Coast Shelf Sci 67: $484-490$

- Strmečki S, Plavšić M, Ćosović B, Ostatná V, Paleček E (2009) Constant current chronopotentiometric stripping of sulphated polysaccharides. Electrochem Commun 11: 2032-2035

Strmečki S, Plavšić M, Ćosović B (2010) Chronopotentiometric stripping analysis of ' $\mathrm{N}$-catalyst' in sodium chloride solution and seawater. Electroanalysis 22:91-98

Tang D, Shafer MM, Karner DA, Armstrong DE (2005) Response of nonprotein thiols to copper stress and extracellular release of glutathione in the diatom Thalassiosira weissflogii. Limnol Oceanogr 50:516-525

Taylor SW, Luther GW III, Waite JH (1994) Polarographic and spectrophotometric investigation of iron(III) complexation to 3,4-dihydroxyphenylalanine-containing peptides and proteins from Mytilus edulis. Inorg Chem 33:5819-5824

- Tomschik M, Havran L, Fojta M, Paleček E (1998) Constant current chronopotentiometric stripping analysis of bioactive peptides at mercury and carbon electrodes. Electroanalysis 10:403-409

Tsang JJ, Rozan TF, Hsu-Kim H, Mullaugh KM, Luther GW (2006) Pseudopolarographic determination of $\mathrm{Cd}^{2+}$ complexation in freshwater. Environ Sci Technol 40: 5388-5394

van den Berg CMG (1982) Determination of copper complexation with natural organic-ligands in sea-water by equilibration with $\mathrm{MnO}_{2}$ : I. Theory. Mar Chem 11:307-322

> van den Berg CMG, Nimmo M, Daly P, Turner DR (1990) Effects of the detection window on the determination of organic copper speciation in estuarine waters. Anal Chim Acta 232:149-159

Verdugo P, Alldredge AL, Azam F, Kirchman D, Passow U, Santschi P (2004) The oceanic gel phase: a bridge in the DOM-POM continuum. Mar Chem 92:67-85

Verweij W (2007) CHEAQS pro. http://home.tiscali.nl/cheaqs (accessed March 2009)

> Vojvodić V, Ćosović B (1996) Fractionation of surface active substances on the XAD-8 resin: Adriatic Sea samples and phytoplankton culture media. Mar Chem 54:119-133

Wagener T, Pulido-Villena E, Guieu C (2008) Dust iron dissolution in seawater: results from one-year time series in Mediterranean Sea. Geophys Res Lett 35:L16601 doi:10. 1029/2008GL034581

- Wells ML, Kozelka PB, Bruland KW (1998) The complexation of 'dissolved' $\mathrm{Cu}, \mathrm{Zn}, \mathrm{Cd}$ and $\mathrm{Pb}$ by soluble and colloidal organic matter in Narragansett Bay, RI. Mar Chem 62: 203-217

> Wen LS, Santschi P, Gill G, Paternostro C (1999) Estuarine trace metal distributions in Galveston Bay: importance of colloidal forms in the speciation of the dissolved phase. Mar Chem 63:185-212

Wurl O, Holmes M (2008) The gelatinous nature of the seasurface microlayer. Mar Chem 110:89-97

Zhang S, Xu C, Santschi PH (2008) Chemical composition and $234 \mathrm{Th}$ (IV) binding of extracellular polymeric substances (EPS) produced by the marine diatom Amphora sp. Mar Chem 112:81-92

Zhou J, Mopper K, Passow U (1998) The role of surface-active carbohydrates in the formation of transparent exopolymer particles by bubble adsorption of seawater. Limnol Oceanogr 43:1860-1871

Submitted: August 26, 2009; Accepted: February 24, 2010 Proofs received from author(s): May 20, 2010 